International Journal of Instruction e-ISSN: 1308-1470 • www.e-iji.net

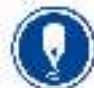

Article submission code: 20190326083547
Received: 26/03/2020

Revision: 02/10/2020
April 2021 • Vol.14, No.2

p-ISSN: 1694-609X

pp. $535-550$

Accepted: 24/10/2020

OnlineFirst: 07/02/2021

\title{
English as a Foreign Language: Listening to Students and Teachers, a Case Study in LAO PDR
}

\section{Mar Gutiérrez-Colón}

Universitat Rovira i Virgili (URV), Spain, mar.gutierrezcolon@urv.cat

\section{Phetsavanh Somsivilay}

Savannakhet University (SKU), Spain, somsivilay88@gmail.com

\begin{abstract}
This paper examines factors relating to teaching English at a public university in LAO PDR in order to, firstly, ascertain those issues that inhibit the development of proficiency in English and, secondly, to identify possible solutions. The following research question was posed: What factors are needed in Lao PDR to improve English language learning at the university level? Information for the study was gathered using questionnaires designed for and distributed to teachers and students. Both quantitative and qualitative data was analysed and a comparison made between the responses drawn from the two different groups. The solution is not a simple one, but the results identify a clear path forward. A significant problem identified in this study is the existence of different views regarding the learning process and the level of English language proficiency achieved by students at the completion of their degree. One of the proposed actions is as follows: implementing a language level test conducted at the beginning of each year that would provide teachers with a more reliable idea of what the starting point should be. They would then be able to create their curriculum using whatever materials they consider necessary. It would also be important to have smaller groups and for teachers to collaborate on the design of the materials and the activities and to reach an agreement as to which methodology should be used for each level. Since Laos's Higher Education system is very young, many teachers lack experience. Our suggestion is to form working groups of experienced teachers together with novel teachers to help each other.
\end{abstract}

Keywords: teacher training, English language teaching, laos higher education, teachers' language proficiency, language teaching in laos

\section{INTRODUCTION}

English is used internationally for communication and commerce, and many countries understand its importance. This is particularly the case in developing countries, where the use of English has a significant role in attracting tourism and in influencing education. Consequently, many higher education institutions have developed an English 
language curriculum in order to improve their students' ability to respond to the increasingly global context in which they operate.

Lao People's Democratic Republic (Lao PDR) is a developing, landlocked country located in the heart of Indochina in Southeast Asia. English had been taught as a second language in schools between the 1910s and World War II (Kounnavongsa, 2015) and after, Laos established its independence in 1975 (Stuart-Fox, 1997), the French system of education was introduced. Later in 1986, when Lao PDR launched a program of structural reform known as the New Economic Mechanism (NEM) to accelerate the transition from a centrally planned economy to a market-oriented one, English became one of the pillars of Lao education (Intarapanich, 2013). However, Laos is a developing country, and there are few opportunities for students to study or practice their English. Most students study at school without access to authentic materials and have little or no opportunity to practice with native speakers or even experienced English speakers.

In the Lao educational system, English is a compulsory subject at university and is studied by students throughout their degree. As a developing country, LAO PDR attracts the interest of many international organizations, and it has been noted by Bouangeune, Sakigawa \& Hirakawa (2008) that the demand for English is increasing in Laos in response to the needs of employers. The economy has been improving over recent years, and the degree of investment in tourism and in industry has grown, making English a basic pillar of their future careers.

Even though English has a high priority in the university curriculum, English levels remain low which, according to Souriyavongsa, T., et al. (2013), Rany, Mohamad \& Leong (2013), this is because Lao students lack a basic background in English and, as it is compulsory, lack motivation. Another major factor affecting language development is the use of inappropriate teaching strategies by instructors who are themselves often poorly trained (for example, drilling grammar activities throughout the session). Given this, teachers are unable to engage with students and cannot influence student effectiveness (Souriyavongsa, T., et al. (2013), Rany, Mohamad \& Leong, 2013; Khader \& Shaat, 2011).

Many graduate students in Lao PDR plan to apply to labour markets located in the capital and in large provinces, but their ability to find employment is impacted by their low levels of English proficiency. An absence of skilled employees with a proficient level in English impacts negatively on tourism and industry, undermining the economy and affecting the country's ability to internationalise. The result of a survey of employers in 2014 showed that students graduating from higher education institutions lacked professional, analysis, management and working skills and were not meeting the needs of employers (Education Sector Development Plan 2016-2020, Ministry of Education and Sport, Lao PDR, December 2015).

With this need in mind, this study focused on what is required of education in Lao PDR, in particular on the English language skills of university students. The specific aim was to investigate those factors relating to the teaching of English at a public university, which can be representative of any other in the country, in order to, firstly, ascertain 
those issues that seem to inhibit the development of proficiency in English and, secondly, to identify possible solutions. The following research question was posed: What factors are needed in Lao PDR to improve English language learning at the university level?

\section{Literature review}

Although English was introduced in the Higher Education System after Laos entered into the Association of Southeast East Asian Nations (ASEAN) in 1996 (Kounnavongsa, 2015), it remains a new field in terms of research and the results of those new policies that have been introduced are not yet apparent. Of note is that universities began to include the English language in their curriculums without having conducted a needs analysis. It is also the case that in each institution, the English language syllabus is developed by the teachers who base it on their own knowledge and what they consider to be the needs of their students. Consequently, there is no national strategic plan addressing English language teaching, since university degrees do not include a general plan, established by the Government, for the acquisition of a second language.

The term "needs analysis" describes the process of recognising issues within a target population and then identifying potential solutions (Ruiying \& Allison, 2003). It is a valuable analytical technique used to define the source of issues occurring within a specific group and, in education, seeks a better understanding of the needs of learners in order to develop effective curricula and plan successful courses. It involves carrying out some activities with learners in order to find out which approach will help them to improve their knowledge and abilities efficiently.

\section{English Language in Higher Education in Laos}

In 1995, higher education was reformed by the Lao government in both the public and private education sectors. The National University of Laos (NUOL) was established as a key stimulus for the reforms introduced by the Prime Minister's Decree on Private Higher Education. This Decree was revised in 2000, and in 2001 the Decree of the Higher Education Curriculum (National Standard) was established (Seameo Rihed UNESCO, Bangkok, 2006).

As an international language for communication, there has been an increasing need in Lao over the last twenty years to learn English in response to the foreign investments that have taken place. English became crucial in 1996 when Lao PDR became a member of the Association of Southeast East Asian Nations (ASEAN) and even more so in 2012 with the membership of the World Trade Organization (WTO) (Souriyavongsa, T., et al. (2013). Consequently, the government now pays much greater attention to English in higher education. According to Kounnavongsa (2015), it has been an official strategy to introduce the use of the English language in schools from year three, with English being used as a medium of instruction at other appropriate levels. This fact has provided more background on use during primary and secondary education. There is also support from the government in the provision of teaching materials. 


\section{Self-confidence and Second Language Learning}

Confidence has a crucial role in language acquisition. As Brown (1994) highlighted selfesteem, or level of confidence, is a crucial element for learners to be successful. Further, according to Dislen (2013), emotion plays a significant role in language acquisition and can determine success in language learning. The consequence of a limited basic background and a culture in which children are not taught to express their opinions in the early stages is that students are not confident users of a second language. Students also find it challenging to develop higher-level language skills because of shyness and a fear of making mistakes (Souriyavongsa, T., et al. (2013) et al; 2013a).

According to Souriyavongsa, T., et al. (2013) et al. (2013a), key issues are adequate curriculum design and having a good syllabus while inappropriate instructional materials and poor teaching methods and learning strategies can cause Lao students to perform poorly when learning English as a foreign language (Souriyavongsa, T., et al. (2013) et al. 2013b). Khader \& Shaat (2011) also point out that, for Lao students, the disciplines and drills, common in traditional instructional design, can also negatively affect negatively the achievement gap in language learning.

\section{METHOD}

\section{Participants}

Participants in this study came from two different groups within this University in Laos: English language teachers $(\mathrm{N}=20 ; 65 \%$ males and $35 \%$ females $)$ and students $(\mathrm{N}=33$; (72.7\% females, and $27.7 \%$ males). The twenty teachers were in charge of academic and administrative matters for six English classes offered from the first to the fourth year. The thirty-three English students were in their third year.

\section{Data collection}

To gather information relating to the teaching and learning of English, two categories of questionnaires were designed and distributed randomly to two groups of participants (Appendix 1a-1b). All two questionnaires were issued online through a survey link, and the return rate was $100 \%$ for the students, and $85 \%$ for the teachers. All 50 completed questionnaires were then subject to data analysis.

Questionnaires eliciting both quantitative and qualitative information were created and validated by a group of students (5) and teachers (3) who answered the questions and sent their comments related to conent improvements to the authors of the research. Then, they were sent via email to the teacher participants and those that had to be answered by students, were sent to teachers who asked their students to answer them (this was done to ensure a higher participation). The characteristics of the questionnaires were the following:

- The student questionnaire included two sections with a total of 19 questions. The first section covered general information and the second attitudes toward the English language class. 
- The teachers' questionnaire contained three sections containing a total of 22 questions. The first section covered general information, the second, academic data, and the third covered attitudes towards teaching English.

- All questionnaires were delivered to participants in an electronic format, and the participants responded via email, Facebook, and WhatsApp using a link provided by the researchers.

\section{Data analysis}

Quantitative data was analysed using the Statistical Package of Social Sciences (SPSS) program. A descriptive analysis of frequency, percentage, mean, and standard deviation was conducted for all the quantitative items in the questionnaire to explore satisfaction levels amongst teachers and students with regard to teaching and learning processes, problems and potential solutions.

Qualitative data obtained from open-ended questions included in the questionnaires was analysed by thematic coding, and the information provided was categorized.

\section{FINDINGS}

The analysed data from the two groups of participants (students and teachers) is presented below.

In this construct, all the quantitative data collected from the questionnaires was analyzed using Microsoft Excel; specifically, the frequency and percentage were calculated to describe general information and academic data. With the Statistical Package of Social Science (SPSS) program, the mean and stand division were calculated to analyze the satisfaction levels of the teachers and students on the process and the frequency of occurrence of the teachers' actions in a semester. At this point, a five-point Likert Scale was used as the following table shows :

$\begin{array}{lll}\text { Teachers } & \text { Averages mean score } & \text { Rating score } \\ \text { Frequency of satisfaction } & \text { 5: Not at all } & 5.00-4.20: \text { Not at all } \\ \text { of their teaching } & \text { 4: Not much } & 4.19-3.40: \text { Not much } \\ \text { outcome } & \text { 3: Neutral } & \text { 3.39-2.60: Neutral } \\ & \text { 2: Somewhat } & \text { 2.59-1.80: Somewhat } \\ & \text { 1: Very much } & 1.79-1.00: \text { Very much } \\ \text { Frequency of occurrence } & \text { 5: Never } & \text { 5.00-4.20: Never } \\ \text { of the teachers' actions } & \text { 4: Rarely } & 4.19-3.40: \text { Rarely } \\ & \text { 3: Sometimes } & \text { 3.39-2.60: Sometimes } \\ & \text { 2: Often } & \text { 2.59-1.80: Often } \\ \text { Students } & \text { 1: Always } & 1.79-1.00: \text { Always } \\ \text { Students' satisfactions } & \text { Averages mean score } & \text { Rating score } \\ \text { with the class } & \text { 4: Agree } & \text { 5.00-4.20: Totally agree } \\ & \text { 3: Undecided } & \text { 4.19-3.40: Agree } \\ & \text { 2: Disagree } & \text { 3.39-2.60: Undecided } \\ & \text { 1: Totally disagree } & \text { 2.59-1.80: Disagree } \\ & \end{array}$


The teachers' was indicated by:

\section{The Students}

More than half of the students $(54.5 \%)$ believed themselves to be at an intermediate level (B2.1), 24.2\% considered themselves to be at an intermediate level B1.2, and $12.1 \%$ described themselves as being at an lower-intermediate level (B1.1). 9.1\% of students defined their proficiency level at upper-intermediate (B2.2). When asked about why they were taking English language classes almost half of the participants (42\%) said they thought it would be useful for their future careers, $18.8 \%$ took the course because they liked the subject, $17.4 \%$ planned to enrol on a master's degree abroad and $7.2 \%$ had selected the course to get an academic certificate.

More than half of the participants (54.5\%) thought that, in English, speaking is the most useful skill $39.4 \%$ considered reading to be a constructive skill, and $6.1 \%$ believed listening to be the most useful skill.

The responses also provide an image of their attitudes towards the English language class with students expressing a positive attitude towards the class with an average meaningful level between 3.42 and 3.90, meaning that the class was interesting and enjoyable. The responses also indicated that the students thought that the curriculum was appropriate for their level and that the activities were well designed and suitable for the learning context. However, even though students had positive attitudes towards the class, they were not as positive towards the teaching-learning process as demonstrated by their responses to the question of whether the lessons met their needs with the results showing an average meaningful level of 2.27, indicating a low level of satisfaction.

Based on the responses from the student participants, a major challenge when learning English is the different language skills. Furthermore, students described the problem of a lack of confidence. These two issues result in students becoming passive learners.

In regard to their favourite aspects of the course, students liked practicing different skills in different activities. Class activities like group work, listening to songs, or having activities in class in which they are the centre of the learning process were the aspects in which they were most interested. As for their instructors, students said that they would like to have some native speakers of English language teachers.

When asked about what they did not like about the course, the students identified: the use of the mother tongue in class, a lack of proficient language teachers and that, sometimes, the teaching methods made the class boring. Students also thought the teaching materials could be improved.

The questionnaire also asked the students to make suggestions as to how they thought the learning-teaching process might be improved. Their responses were grouped as follows:

- Instruction: many students suggested that teachers should explain the lesson more clearly, should pay attention while teaching, improve their teaching methods and 
improve their English level. They thought that more speaking practice in class is needed and that different teaching resources, not just textbooks, should be used

- Skills: students suggested that there should be a greater focus on reading skills, on grammar and on speaking and listening. It appears that, for students, speaking was the most important.

- Materials: students thought that the university should provide more teaching materials and use more audio-visual aids in order to improve students' language skills, on the basis that the more practice they have, the better the results.

- Native speaking teachers: students considered that having more native teachers was a necessity.

- Attention: interestingly, students also highlighted the need for students to pay more attention to the teacher if they are to have a better understanding.

\section{The Teachers}

The data shows that the teachers are relatively young: $75.5 \%$ were between $24-$ and $30-$ years-old, with only four between 31- and 45-years. All of the teachers (100\%) held a bachelor's degree (all in the English Language). More than half of them (58.8\%) had 13 years of teaching experience, $23.5 \%$ had been teaching for 4-6 years, and only a few respondents had more than 6 years of teaching experience (17.6\%).

The university has a training for trainers program, and it is considered important for teachers to attend. Responses to the questionnaire indicate that of those teachers responding, $76.5 \%$ had completed this course.

Concerning the language of instruction, sixteen of the seventeen teachers who returned the questionnaire said that they used English as the language for instruction in their classes. The teacher using the L1 in class, argued that it was difficult for students to understand the teacher when they were at a beginner level. The data also reveals that $70.6 \%$ of the teachers described themselves as being confident when teaching English, and that those who lacked confidence $(29.4 \%)$ did so because they were inexperienced teachers. All of the teachers (100\%) thought they were teaching an appropriate level for university students.

All the participant teachers said that they planned the lesson in advance of the class, although the methodology was different: $47.1 \%$ said that they followed the index of a book, $41.2 \%$ created their own syllabus, and only $11.8 \%$ used a course already in existence. When asked in more detail about the materials that they used, more than half of the participants (52.9\%) said they used visual aids (videos, basically) when teaching, and $23.5 \%$ used audio-visual aids (video and songs). Audio aids were used by $17 \%$ of the teachers, and only one said they used teaching material from the internet.

Regarding their teaching strategies, the data reveals that $33.3 \%$ used the PresentationPractice-Production method, 25\% used a Task-Based and Communicative Approach, 
and $13.9 \%$ used the Grammar Translation Method to teach in class. Interestingly, one participant stated that she used her own method, but no details were provided.

Teachers were also asked about the contribution to English language teaching made by policymakers at the university. While most teachers $(88 \%)$ felt they had support from the policymakers $11.8 \%$ thought that the support from policymakers was inadequate, in particular they felt that they do not have sufficient teaching materials, nor enough time and the right support to attend training courses that would enhance their teaching abilities.

The teachers were positive about the quality of their teaching, fully believing that their lesson plans and their teaching methods met the needs of their students (mean=1.70). They also thought that the content of the coursebook was concise and covered relevant topics (mean=1.76) and that the current curriculum was very much appreciated by the students (mean=1.70). The six main components of the teaching process that were considered most effective are: teacher satisfaction with the classes, the success of their teaching process, the achievement of the goal, teaching quality and skills, and the cooperation and attention of students. All of these were found to have means between 2.00 and 2.47 .

The teachers also provided some qualitative data specifically relating to the challenges they were facing: 1) the groups were too big (around 30 students per group), 2) the different levels of proficiency and a lack of motivation amongst the students, 3) low proficiency levels amongst the teachers 4) limited experience in teaching languages, 5)the lack of teaching materials and the multitude of tasks required of teachers outside of their teaching obligations.

\section{DISCUSSION}

Analysis of the qualitative and quantitative data gathered from the two groups of participants (students and teachers), reveals that the factors needed in Lao PDR to improve English language learning at the university level is really complex, since many elements are involved. Accordingly, this section focuses on the main issues hindering improvement in language learning.

A significant issue identified in this study is the misperception that students have of their English level, with many believing it to be higher than the reality. While $54.8 \%$ of the student participants considered themselves to have a B2.1 level, and $9.1 \%$ thought that were at a B2.2 level it was apparent from their written responses to the questionnaire that most could not compose basic sentences in English and that many of them had stated that they were unable to understand the words spoken nor produce an utterance of their own when communicating with foreigners. This finding is similar to that of Souriyavongsa, T., et al. (2013) et al. (2013), who found that proficiency levels in English were quite low amongst Lao students. An interesting question, when considering this issue in relation to the belief, expressed by the teacher participants, that they were teaching at an appropriate level, is what exactly is that level? As far as could be established and bearing in mind that the student participants were in their third year of university and would have studied English in earlier years, there appeared to be no level 
testing, nor even a diagnosis of levels. Another issue, intertwined with misperceptions regarding levels, is the lack of confidence experienced by students when using English. This lack of confidence results in them becoming, for most of the time, passive learners. Students also report themselves as being very shy, something which inhibits interaction with native speakers (or indeed with their teachers). This finding reflects the findings of other studies, for example, Tokoz-Goktepe (2014) who found that problems associated with speaking were associated with the student's fear of making mistakes, to this we might add the particular characteristic of Laos students is that they can be very quiet and shy in class and not eager to ask questions or express doubts to the teacher.

According to the students, speaking is the most important skill, followed by reading and then listening. According to the teachers, the most frequently used approaches were doing presentations, followed by practice and production (33.3\%), a task-based approach $(25 \%)$ and the grammar-translation method (14\%). There would appear to be few opportunities for students to practice speaking skills nor to place students at the centre of the learning process (where they said they would like to be). The use of these approaches is the most likely explanation for why some students have described the teaching methods as "boring." Interestingly, the policymaker participants also noted that many teachers were not using the right methods in classes. Another interesting mismatch relates to the language of instruction. While $94.1 \%$ of instructors stated that they used English as the language of instruction, according to the student participants the L1 was used in most of the teaching time. Even though it is believed that using L1 in the language classroom can be helpful for students (Scrivener, 2005), the responses of the student participants in this study see the use of the L1 as a negative. This reflects the findings of Souriyavongsa, T., et al. (2013), et al. (2013) who found that the use of the first language by the teacher caused students to have low proficiency levels. Also, of concern in this study, given that the teacher participants all had a degree in English, is the finding that $29.5 \%$ of teachers lacked confidence when using the L2 in the classroom, a percentage that ought to be zero given their qualification.

As seen in the teachers' responses, in contrast to the opinions of the students (who believed that their instructors used inappropriate teaching methods), teachers held positive views about the quality of their teaching. Furthermore, they were confident that, alongside their high-quality teaching, their teaching skills were also good, a view that contrasted with that expressed by the students who felt that classes were not interesting and their teachers were not qualified enough.

Also, $41.2 \%$ of the teachers expressed concern about the adequacy of the teaching resources provided by the university. Likewise, responses from students suggested that in their classes, there were not enough documents or course books and that the use of new technologies was very low, all factors which contribute to low student performance in the classroom. Seven and Engin (2007) found that those students who had a positive attitude regarding the use of materials displayed greater levels of permanent retention of knowledge. Warschauer (1996) has argued that, in language learning, the use of technology has been key in encouraging and reinforcing students' perceptions, that is, it inspires students to practice the language and helps them to increase their language 
skills. Given these findings, it is reasonable to conclude that a lack of teaching materials may cause low attention rates amongst students.

Another issue that is important to be taken into account is the size of the groups: teachers described having around 30 students in each class, and that these groups were multi-level. Groups of this size and character may well affect student motivation as it is impossible for the teacher to respond to all of the needs of all of the students; consequently, some students may feel bored, and others may feel that they are making no progress. This reflects Krashen's Input Hypothesis (1987), which argues that the learner can only improve in their acquisition of a second language when he/she receives second language input that is one step beyond his/her stage of L2 competence.

Interestingly, both teacher and student participants expressed similar views regarding how to improve the teachers' knowledge and abilities in relation to English language teaching. For example, it was suggested that the teacher should explain the lesson more clearly in English, pay more attention to the class (that is, make sure that the students are following the explanations provided), take into account the diverse student levels, use the target language as the primary mode of instruction, learn different teaching approaches, and devote more time to students' needs analysis and lesson planning so that a greater variety of teaching aids might be provided. In addition, both the teachers and the students highlighted the need to provide greater opportunities for practice in class and to decrease the number of teacher-centred lessons.

\section{CONCLUSION}

This study exposes the different and almost opposite views held by the two groups of participants (students and teachers). A significant problem identified in this study is, therefore, the existence of dissimilar views regarding the learning process and the level of English language proficiency achieved by students at the completion of their degree.

As students clearly have a lower proficiency level than what they perceive themselves to have, a language test conducted at the beginning of each year would provide teachers with a more reliable idea of what the starting point should be they would then be able to create their own curriculum using whatever materials they consider necessary. It would also be important to have smaller groups and for teachers to collaborate in the design of the materials and the activities and to reach an agreement as to which methodology should be used for each level. In this way, if a teacher is more comfortable using the Grammar Translation method, this could be applied to some activities during the different courses (each course taught by at least two teachers), or with groups of students who need to focus on grammar. Adopting such a collaborative approach, teachers could share ideas and learn from each other.

An important characteristic is that all the universities in the country are new. In newer universities, teachers tend to be positive, full of energy and with a high level of motivation. However, this can mean that they fail to see the whole picture, essentially because the teachers may lack experience. In such circumstances, teachers could seek the help of a senior teacher who might then mentor them for one or two years (maybe 
this could be one of the policymakers' tasks). This novelty and lack of experience reach an end with time spent on the job.

It is also proposed that one of the first things that should be done is to revise the Training for Trainers courses. The effort of the university in offering these teacher training courses should be acknowledged, but the key issue is whether the content of these courses accords with the needs of the teachers.

Finally, our last proposal would be that mobility programmes should be increased and improved, since we believe that these international experiences would open both teachers' and students' minds and would make them see in a more professional way, the necessity of acquiring a good language proficiency level.

\section{REFERENCES}

Brown, H.D (1994). Principles of language Learning and Teaching. Chapter 6: Personal Factors. Practice Hall. 136-138.

Bouangeune, S., Sakigawa, M., \& Hirakawa, Y. (2008). Determinants and issues in student achievement in English at the Lao Secondary Education Level. The Asian EFL Journal, 10(1), 48-64.

Dişlen, G. (2013). The Reasons of Lack of Motivation from the Motivation from the Students' and Teachers' voices. The Journal of Academic Social Sciences, 1, 35-35.

Education Sector Development Plan 2016-2020 (2015). Ministry of Education and Sport, Lao PDR. http://www.dvv-international.la/fileadmin/files/south-and-southeastasia/documents/ESDP_2016-2020-EN.pdf

Intarapanich, C. (2013). Teaching methods, approaches and strategies found in EFL classrooms: A case study in Lao PDR. Procedia-Social and Behavioral Sciences, 88, 306-311.

Kounnavongsa, S. (2015). An Overview of the State of Language Policy/Practice in Lao PDR. English for ASEAN Integration: Policies and Practices in the Region, 65.

Kramsch, C. (2000). Second Language Acquisition, Applied Linguistics, and the Teaching of Foreign Languages, The Modern Language Journal 84, 332.

Krashen, S. D. (1987). Principles and Practice in Second Language Acquisition. Prentice-Hall International.

Khader, K. T., \& Shaat, M. (2011). Reasons behind non-English major university students' achievement gap in English language in Gaza Strip from students' perspectives. Conference paper: First National Conference on "Improving TEFL Methods \& Practices at Palestinian Universities": https://www.qou.edu/english/conferences/firstNationalConference/pdfFiles/khaderKhad er.pdf 
Ruiying, Y. \& Allison, D. (2003). Research articles in applied linguistics: structures from a functional perspective. English for Specific Purposes, 23(3), 264-279. https://doi.org/10.1016/S0889-4906(03)00005-X

Scrivener, J., (2005). Learning Teaching: A Guidebook for English Language Teachers. Macmillan.

Seameo Rihed (Southeast Asian Ministers of Education Organisation. Regional Centre for Higher Education and Development). (2006). Higher education in South-East Asia. Decree of the Higher Education Curriculum (National Standard) in 2001. UNESCO Bangkok. Asia and Pacific Regional Bureau for Education. http://unesdoc.unesco.org/images/0022/002272/227242e.pdf

Souriyavongsa, T., Rany, S., Abidin, M. J. Z., \& Mei, L. L. (2013). Factors causes students low English language learning: A case study in the National University of Laos. International Journal of English Language Education,1(1), 179-192.

Souriyavongsa, T., Abidin, M. J. Z., Sam, R., Mei, L. L., \& Aloysius, I. B. (2013). Investigating Learning English Strategies and English Needs of Undergraduate Students at the National University of Laos. English Language Teaching, 6(10), 57-71.

Seameo Rihed (2006). Higher education in South-East Asia. UNESCO Office Bangkok and Regional Bureau for Education in Asia and the Pacific [860], SEAMEO Regional Centre for Higher Education and Development. https://unesdoc.unesco.org/ark:/48223/pf0000146541

Seven, M. A., \& Engin, A. O. (2007). The Importance and Effect of Using Aid Materials. Foreign Language Teaching Proceedings. https://files.eric.ed.gov/fulltext/ED497456.pdf

Stuart-Fox, M. (1997). A history of Laos. Cambridge University Press

Titcomb, A.L. (2000), ICYF Evaluation Concept Sheet. University of Arizona. https://www.scribd.com/document/65262252/Needs-Analysis .

Tokoz-Goktepe, F. (2014). Speaking problems of 9th grade high school Turkish learners of L2 English and possible reasons for those problems: Exploring the teachers and students' perspectives. Procedia- Social and Behavioral Sciences, 116, 1875-1879.

Warschauer M. (1996). Computer assisted language learning: An introduction. In S. Fotos (Ed.), Multimedia language Teaching, 3-20. Tokyo: Logos International.

Yin, C. (2008). Language learning strategies in relation to attitudes, motivations, and learner beliefs: investigating learner variables in the context of English as a foreign language in China. Doctoral dissertation. Digital repository at the University of Maryland. https://drum.lib.umd.edu/handle/1903/8258 


\section{Appendix}

Appendix 1a: Questionnaire for students

This survey has been designed to help better understand the current situation of learning-teaching English as a second language in Savannakhet University. The results of this questionnaire will be used for the improvement of teaching English in the future. You are kindly requested to answer the questions below. The survey should take about five minutes of your time.

The questionnaire is divided into 3 sections:

Section I: General data

1. Gender $\square$ Male $\square$ Female

2. Did you learn English at school?

$\square$ Yes (how many years?)

$\square$ No

3. What is your English level?

$\square$ Beginner (A1) $\square$ Elementary (A 2)

$\square$ Intermediate (B1) $\square$ Upper- intermediate (B2)

$\square$ Advanced (C1) $\quad \square$ Proficiency (C2)

4. What is the reason to take an English language subject during your degree?

$\square$ you like this field of study

$\square$ you plan to take master degree aboard

$\square$ English will be useful for your job

$\square$ to attain the academic certificate of English degree

$\square$ it is your family's wish

$\square$ you have no other choice

$\square$ other ( please specify)...

\section{Section II: Attitudes toward learning English}

5. Do you think English is important for your future careers?

$\square$ yes

6. What is your expectation in learning English? (you can choose more than one)

$\square$ to use it in social communication

$\square$ to use it on specific purpose (travelling, living aboard, for your own business...)

$\square$ to accomplish your goal at work

$\square$ to get the scholarships

$\square$ to improve your knowledge

$\square$ To pass the exam

$\square$ other ( please specify).

7. What is the most useful English skill for you? ( please tick one option only)

$\square$ speaking

8. What are your major challenges/problems in learning English?

9. Does anybody in your family speak English?

$\square$ Yes (who?)

$\square$ No

10.Do you imagine yourself communicating in English with a foreign person?

$\square$ Yes

$\square$ No

11.Does the former image make you feel happy?

$\square$ Yes

$\square$ No

12.Are you un contact with the English language out of the class? (television, music, internet, chats, other...)

$\square$ Yes

$\square$ No 
Section II: Attitude toward the class

Please $(\checkmark)$ rate your attitudes toward the English language class using the following scales:

$1=$ totally disagree, $2=$ disagree, $3=$ undecided, $4=$ agree, $5=$ totally agree

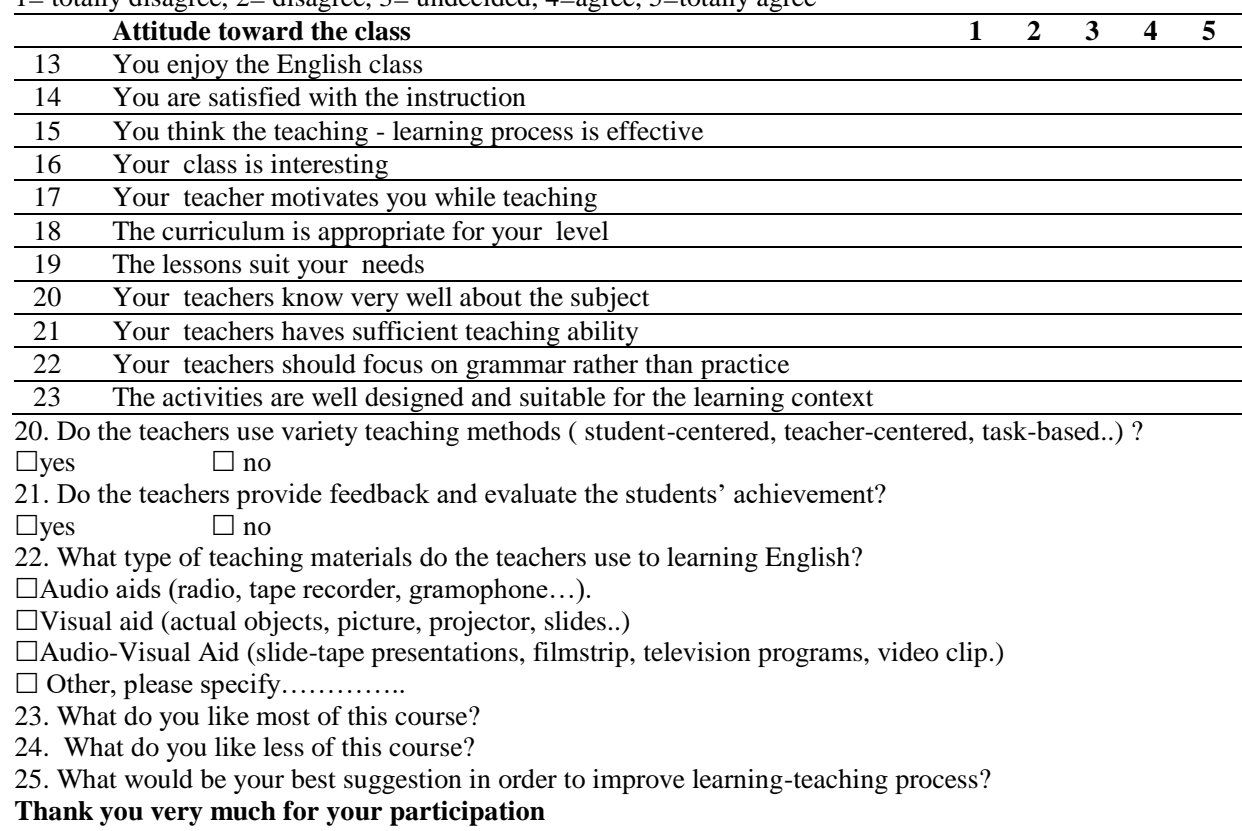

Appendix 1b: Questionnaire for teachers

This survey has been designed to help better understand the current situation of learning-teaching English as a second language in Savannakhet University. The results of this questionnaire will be used for the improvement of teaching English in the future. You are kindly requested to answer the questions below. The survey should take about five minutes of your time.

The questionnaire is divided into 3 sections:

Section I: General information
1. Gender
$\square$ Male
$\square$ Female

2. Age

$\square$ under 23 years old $\square$ 24-30 years old

$\square 31-45$ years old $\quad \square>46$ years old

3. What level of education have you attained?

$\square$ Diploma Degree $\square$ Bachelor Degree

$\square$ Master Degree $\quad \square$ Doctoral Degree

4. How many years of teaching experience have you had?

$\square$ 1-3 years $\square$ 4-6 years $\quad \square>6$ years

5. What is your major file of study?

$\square$ English $\square$ Other, please specify

6. Have you completed the training of trainer (TOT) course?

$\square$ yes

$$
\square \text { no }
$$

Section II: Academic data

7. How many hours do you teach per week?

$\square 4$ hours $\square 6$ hours $\square>6$ hours

8. How many subjects are you assigned to teach for one semester?

International Journal of Instruction, April 2021 •Vol.14, No.2 
$\square 1$ subject $\quad \square 2$ subjects $\quad \square>2$ subjects

9. How many students do you have per session?

[write here possible number of groups]

10.Do you use English as the language for the instruction?

$\square$ Yes

$\square$ no (in this case, why)

11.Do you feel confident teaching in English language?

$\square$ yes

$\square$ no (in this case, why)

12.Are you teaching the level of English language that you think should be taught at university? $\square$ Yes

$\square$ No (in this case: higher or lower?)

13.Do you regularly plan the lessons before the class?

$\square$ yes

14. What type of syllabus do you have?

$\square$ I create the syllabus on my own

$\square$ I use an already existing course

$\square$ I follow the index of a book

$\square$ Other, please specify.

15. What kind of teaching strategy do you usually use? (you can choose more than one)

$\square$ Task based approach

$\square$ Communicative approach

$\square$ Grammar translation

$\square$ Present practice production (PPP) method

$\square$ Other, please specify.

16. What category of teaching materials do you use to teach

$\square$ Audio aids (radio, tape recorder, gramophone...)

$\square$ Visual aid (actual objects, picture, projector, slides...)

$\square$ Audio-Visual Aid (slide-tape presentations, filmstrip, television programs, video clip...)

$\square$ Other, please specify

17. What challenges do you think the English language teachers face in this university?

18. What challenges do you think the English language teachers face when planning lessons in this university?

19. What would you suggest in order to improve the quality of learning-teaching process?

20.As second language teacher, do you feel that English language is considered by your students an important subject?

$\square$ yes

$\square$ no

21.As a second language teacher, do you feel you have support from the policy makers of your university?

$\square$ yes

$\square$ not enough (in this case, why?)

International Journal of Instruction, April $2021 \bullet$ Vol.14, No.2 
Section III: The opinion toward teaching English

Please check $(\checkmark)$ and rate your attitudes toward the English language class using the following scales:

$1=$ very much, $2=$ somewhat, $3=$ neutral, $4=$ not much, $5=$ not at all

\begin{tabular}{|c|c|c|c|}
\hline No & Attitude toward the class & 1 & 4 \\
\hline 22 & You feel satisfied with the classes & & \\
\hline 23 & Your classes achieve the primary goads & & \\
\hline 24 & You encompass high teaching quality & & \\
\hline 25 & You have good teaching skills & & \\
\hline 26 & Your lesson plans and teaching methods meet student needs & & \\
\hline 27 & Your current curriculum is appropriate for students' level. & & \\
\hline 28 & Your department provides enough required teaching materials & & \\
\hline 29 & The content of the coursebook is concise and cover relevant topics & & \\
\hline 30 & Students cooperate and are engaged in their learning & & \\
\hline 31 & Students pay to attention to the lesson & & \\
\hline \multicolumn{4}{|c|}{ How often do you perform the following actions in a semester? } \\
\hline & always & sometime & never \\
\hline 32 & $\begin{array}{l}\text { Encourage students to learn English by } \\
\text { themselves }\end{array}$ & & \\
\hline 33 & $\begin{array}{l}\text { The teachers in the faculty work collaboratively } \\
\text { to solve problems and respond to student needs }\end{array}$ & & \\
\hline 34 & $\begin{array}{l}\text { Provide feedback and evaluate the students' } \\
\text { achievement }\end{array}$ & & \\
\hline 35 & $\begin{array}{l}\text { Use new technology to engage students to take } \\
\text { part of the lesson }\end{array}$ & & \\
\hline 36 & $\begin{array}{l}\text { Organize activities for students to take authentic } \\
\text { practices in door and field trip }\end{array}$ & & \\
\hline
\end{tabular}

International Journal of Instruction, April $2021 \bullet$ Vol.14, No.2 